\title{
Aquaporin 1 (AQP1) regulates plasma membrane bleb formation by facilitating bleb retraction phase in cancer cells
}

\author{
Godwin A. Ponuwei ${ }^{1,2 *}$ and Phil R Dash ${ }^{1}$ \\ ${ }^{1}$ Department of Biomedical Science, Molecular and Cellular Medicine Division, School of Biological Sciences, University of Reading, UK \\ ${ }^{2}$ Department of Biological Sciences, Thompson Rivers University, Williams Lake Campus, Canada
}

\begin{abstract}
Cancer cells migrate by using different membrane protrusions including plasma membrane blebs. Blebs are formed when the plasma membrane delaminates from the underlying cortex due to actomyosin contractility-induced increase in cytoplasmic pressure, and this causes influx of water and cytosolic fluid through aquaporins into the detached membrane resulting in its enlargement. In this study, we used a combination of molecular biology and microscopy techniques to examine the involvement of aquaporin 1 (AQP1) in bleb formation, and report for the first time that, siRNA-mediated knockdown of AQP1 inhibited bleb formation in both HT1080 and ACHN cell lines embedded in 3D matrigel matrix. In HT1080 cells, blebs resurfaced $48 \mathrm{~h}$ post-siRNA transfection, and this paralleled AQP1 protein expression, as shown by Western blotting. By using confocal and phase-contrast time-lapse microscopy to track bleb dynamics, we demonstrate that the re-emergent blebs had longer lifespan due to longer time of expansion, stabilization and retraction when compared with wildtype blebs. Furthermore, overexpression of GFPtagged AQP1 significantly increased bleb size, and also reduced bleb lifespan by conferring on the cells a shorter and faster bleb retraction time. To unravel the mechanism underpinning AQP1-facilitated bleb retraction, our data showed a requirement for the sodium-hydrogen exchanger $\left(\mathrm{Na}^{+} / \mathrm{H}^{+}\right)$activity, as inhibition of the pump's activity attenuated bleb retraction. Similarly, and importantly, we demonstrate that GFP-AQP1 overexpression sufficiently induced blebbing phenotype in non-blebbing MDA-MB-231 cell line. Thus, AQP1 is a potential therapeutic target in combating cancer cell migration.
\end{abstract}

\section{Introduction}

Blebs are spherical herniation formed by actomyosin-mediated contractility resulting in the detachment of the plasma membrane from the underlying cortex [1]. Once initiated, blebs dynamically expand and retract within a short interval of time in response to changes in intracellular hydrostatic pressure, and their life cycle comprises three phases of expansion, stabilization, and retraction [2, 3]. Upon initiation, cellular blebs grow and expand as water and fluids flow from the cytosol into the bleb through the bleb neck. The expansion phase usually lasts between 5-30 seconds and an expanding bleb is initially devoid of actin cytoskeleton [4,5]. Bleb expansion gradually recedes and attains a transient stabilization phase as the flow of water and cytosolic fluids become insufficient to maintain a steady growth [6]. At this point, blebs begin to retract as actin nucleation factors, membranecortex linker proteins such as the ERM (ezrin, radixin and moesin) and motor proteins especially myosin II are recruited to the bleb membrane $[2,5]$. The retraction phase, which is the longest, may persist for up to 120 seconds [7]. Membrane blebbing occurs in different biological and pathophysiological processes including apoptosis [8], cytokinesis $[9,10]$, cell spreading [11-13], viral micropinocytosis [14], embryogenesis [15] and in metastasizing tumour cells [16,17]. When matrix proteolysis is inhibited, cancer cells migrate by squeezing through tiny orifices in the extracellular matrices (ECM) using membrane blebs [18].

The aquaporins (AQPs) are integral transmembrane channels (28$30 \mathrm{kDa}$ ) that permit the transport of either only water or both water and other substances such as glycerol and urea across plasma membranes in response to osmotic gradients produced by the active transport of salts and ions $[19,20]$. Thirteen aquaporin isoforms (AQP0-AQP12) have been identified in different mammalian tissues [21]. Whereas the transport functions of $\mathrm{AQP} 12$ are unknown, the orthodox aquaporins (AQP0, AQP1, AQP2, AQP4, AQP5, AQP6 and AQP8) exclusively transport water, while the aquaglyceroporins (AQP3, AQP7, AQP9 and AQP10) transport water and small solutes like glycerol and urea [2225]. Interestingly, it has been discovered that AQP11 is a transporter of both water and glycerol [26]. Of all AQPs, extensive studies have been carried out on AQP1, which is the best characterized and most widely expressed aquaporin in a variety of human tissues [27-33]. Tissues expressing AQP1, which also functions as a gated-ion channel [34,35], display a great deal of water permeability [36]. Besides transmembrane water transport, AQP1 has been implicated in several pathological conditions including defective urinary concentration [37], nociception [38], enhanced angiogenesis [39,40], and cancer cell migration $[28,36,41]$. Despite its reported involvement in cancer cell migration, the role of AQP1 in the formation of membrane blebs in cancer cells in the ECM has not been investigated.

In the present study, we address this question by utilizing 3D Matrigel matrix as a mimic for the normal human ECM. We demonstrate a novel role of AQP1 in regulating cancer cell blebbing

*Correspondence to: Godwin A. Ponuwei, PhD, Department of Biological Sciences, Thompson Rivers University, Williams Lake Campus, Williams Lake, BC, Canada, E-mail: gponuwei@tru.ca

Key words: aquaporin 1, blebs, cortex, contractility, membrane

Received: April 03, 2019; Accepted: April 15, 2019; Published: April 18, 2019 
by facilitating bleb retraction in a mechanism that requires the activity of the $\mathrm{Na}^{+} / \mathrm{H}^{+}$exchanger. Knockdown of AQP1 by smartpool siRNA inhibited membrane bleb formation in human fibrosarcoma HT1080 and renal adenocarcinoma ACHN cell lines cultured in 3D Matrigel matrix. It was found that in HT1080 cells, AQP1 protein reappeared $48 \mathrm{~h}$ post-siRNA transfection, and this paralleled re-emergence of membrane blebs in this cell line. Live cell imaging and time-lapse microscopy revealed that the reemergent blebs had relatively longer lifespan when compared with blebs in wild-type cells. Overexpression of GFP-tagged AQP1 increased bleb sizes with a concomitant decrease in bleb numbers. A detailed analysis of these blebs revealed that AQP1 significantly conferred faster bleb retraction without any significant effect on the expansion phase. Furthermore, AQP1 overexpression sufficiently induced bleb formation in non-blebbing cells. Finally, to unravel the mechanism of AQP1-facilitated bleb retraction, the present study demonstrates a requirement for the $\mathrm{Na}^{+} / \mathrm{H}^{+}$pump, as inhibition of the pump's activity with its known inhibitor, Ethylisopropyl amiloride (EIPA), ablated the retraction of expanding blebs. Our findings raise novel insight into how AQP1 positively regulate bleb formation. Thus, development of anti-AQP1 agents will be a promising therapeutic strategy in combating different human cancers.

\section{Materials and methods}

\section{Cell culture}

The cell lines used, human fibrosarcoma HT1080, renal adenocarcinoma ACHN and breast adenocarcinoma MBA-MB-231 cells were obtained from HPA culture collections, Salisbury, United Kingdom. Cells were cultured in Dulbecco's modified Eagle's medium (DMEM) supplemented with 10\% (v/v) FBS, 1\% (2 mM) L-glutamine, $1 \%(100 \mu \mathrm{g} / \mathrm{ml})$ streptomycin, $1 \%(100 \mathrm{units} / \mathrm{ml})$ penicillin at $37^{\circ} \mathrm{C}$ in humidified $5 \%(\mathrm{v} / \mathrm{v}) \mathrm{CO}_{2}$ atmospheric air. Cells were maintained and passaged every $48 \mathrm{~h}$. Smartpool human AQP1, AQP3, AQP4 and AQP5 siRNAs were purchased from Fisher Scientific, Loughborough, UK. All antibodies - anti-AQP1 (cat. no: ab65837), anti-AQP3 (cat. no: ab125219), anti-AQP4 (cat. no: ab46182) and anti-AQP5 (cat. no: ab85905) antibodies used for immunocytochemistry and Western blotting were obtained from Abcam Plc, Cambridge, UK. Batimastat (BB-94), PIC set VI (protease inhibitor cocktail VI) and Y27632 were purchased from Calbiochem, Nottingham, UK. Ethylisopropyl amiloride (EIPA) was purchased from Tocris Bioscience, Bristol, UK. All inhibitors were dissolved in DMSO except PIC which was reconstituted in ultra-pure water.

\section{siRNA transfection}

The transfection of HT1080 and ACHN cell lines was performed using DharmaFECT transfection reagent set 4 (T-2004-02) according to the manufacturer's instruction as previously described [6]. Briefly, cells were seeded on 6-well plate at a density of $2 \times 10^{5}$ cells/well and incubated at $37^{\circ} \mathrm{C}$ with $5 \% \mathrm{CO}_{2}$ for $24 \mathrm{~h}$ before transfection. From a $20 \mu \mathrm{M}$ stock siRNA, $5 \mu \mathrm{M}$ siRNA solution was prepared in 1x siRNA buffer ( $20 \mathrm{mM} \mathrm{KCl}, 6 \mathrm{mM}$ HEPES ( $\mathrm{pH} 7.5)$, and $0.2 \mathrm{mM} \mathrm{MgCl}$ ), which itself was prepared from $5 x$ siRNA buffer $(300 \mathrm{mM} \mathrm{KCl}, 30 \mathrm{mM}$ HEPES (pH7.5), $1.0 \mathrm{mM} \mathrm{MgCl}_{2}$ ) and RNase-free water at a ratio of 1:4. Two tubes were set up. To the first and second tubes, an appropriate volume of the $5 \mu \mathrm{M}$ siRNA solution and DharmaFECT transfection reagent were respectively introduced. Media supplemented with only L-glutamine (antibiotic- and serum-free media) was introduced into each tube and both tubes were incubated for $5 \mathrm{~min}$ in the hood. After incubation, the content of the first tube was added to the second and the resulting mixture was resuspended and allowed to complex for 20 min before adding antibiotic-free media to the mixture. Culture media from cells in 6-well plate was removed and $2 \mathrm{ml}$ of the total transfection medium was added into each well and then incubated for 24 and 48 h. The final siRNA concentration used was $25 \mathrm{nM}$, and knockdown of proteins was confirmed by Western blotting.

\section{Transfection with GFP-tagged AQP1}

The transfection of cells with AQP1-GFP was done using Fugene transfection reagent according to the manufacturer's instructions. Briefly, prior to start of experiment, cells were seeded in 6-well plate at a density of $1.5 \times 10^{5} \mathrm{cells} /$ well and incubated overnight at $37^{\circ} \mathrm{C}$ with $5 \% \mathrm{CO}_{2}$ supply. Serum-free media was introduced into eppendorf tubes and optimized volumes of Fugene transfection reagent was directly added to the serum-free media and mixed by gentle 'flicking.' Content was incubated for $5 \mathrm{~min}$ in the hood before adding optimized amounts of AQP1-GFP into the tubes and mixed gently. The content was incubated for another $15 \mathrm{~min}$. Culture media was removed from cells in 6-well plate, and the DNA-Fugene complex was introduced in a dropwise manner and evenly distributed. Cells were then incubated at $37^{\circ} \mathrm{C}$ for $24 \mathrm{~h}$ or $48 \mathrm{~h}$ for uptake and expression of DNA.

\section{Blebbing assay}

The blebbing assay was designed in our laboratory as previously described [6]. Briefly, Growth factor-reduced matrigel (BD Biosciences, UK) was thawed overnight at $4^{\circ} \mathrm{C}$ and kept on ice. Tips, pipettes, plates, glass coverslips, $\mu$-dishes and tubes were chilled at $-20^{\circ} \mathrm{C}$ for $1 \mathrm{~h}$. Confluent cells were rinsed with PBS, trypsinized and then resuspended in cold serum-free media. Cell suspension was carefully added on ice to matrigel in an equivalent ratio and mixed properly. 200 $\mu \mathrm{l}$ of cell-matrigel suspension was plated on glass coverslips in 6-well plates, and on $35 \mathrm{~mm}$ glass-bottomed dishes and then incubated at $37^{\circ} \mathrm{C}$ for $30 \mathrm{~min}$ for matrigel to set. Complete cell culture media was added and cells induced to bleb by blocking proteolytic activities of matrix metalloproteinases (MMPs) and proteases with BB-94 $(1 \mu \mathrm{M})$ and PIC (1:100) respectively in the presence of caspase inhibitor set VI $(10 \mu \mathrm{M})$ which inhibits apoptotic bleb formation. Plates were then incubated at $37^{\circ} \mathrm{C}$ for $18 \mathrm{~h}$.

\section{Determination of cell viability (MTT Assay)}

The viability of cells after treatment with bleb-inducing agents was determined by the reduction of yellow tetrazolium salt, 3-(4,5-dimethylthiazolyl-2)-2,5-diphenyltetrazolium bromide (MTT) by metabolically active cells into intracellular purple formazan which is subsequently solubilized and quantified spectrophotometrically. Briefly, ACHN and HT1080 cells (5 x $10^{4}$ cells/well) were seeded on 24 well plate using phenol red-free media supplemented with $10 \% \mathrm{FBS}$ and $1 \%$ each of glutamine and penicillin/streptomycin and then incubated $24 \mathrm{~h}$ at $37^{\circ} \mathrm{C}$ for cells to adhere to plates. Cells were challenged with BB-94 $(1 \mu \mathrm{M})$ and PIC (1:100) in presence of caspase inhibitor set VI $(10 \mu \mathrm{M})$ before incubating for another $18 \mathrm{~h}$. Culture media was replaced with $500 \mu \mathrm{l}$ of pre-warmed media. MTT stock $(5 \mathrm{mg} / \mathrm{ml})$ was added (1:10 dilution) to a final concentration of $0.5 \mathrm{mg} / \mathrm{ml}$. Cells were wrapped in aluminium foil and incubated for $3 \mathrm{~h}$ at $37^{\circ} \mathrm{C}$ in humidified atmospheric condition with $5 \% \mathrm{CO}_{2}$ supply. $550 \mu \mathrm{l}$ of solubilizing buffer was added and content mixed properly at room temperature before transferring into eppendorf tubes and mixed by vortexing. Samples were incubated for $10 \mathrm{~min}$ at room temperature and then mixed again by vortexing. Absorbance values of blank (background) and test samples were recorded at $690 \mathrm{~nm}$ and $570 \mathrm{~nm}$ respectively using a Jenway spectrophotometer (Stone, Staffordshire, UK). 


\section{Determination of bleb size}

The determination of bleb size was previously described [6]. In brief, a thin line was manually drawn round the entire circumference of each blebs on a cell with the 'polygon' tool of ImageJ. This was followed by 'analyze > measure', and from the dropdown result list, the perimeter values in pixel were recorded. Values in pixel were normalized by multiplying with a pre-calibrated factor of $0.11 \mu \mathrm{m}$ (a factor which corresponds to 1 pixel, and which was obtained when the $40 \mathrm{x}$ objective lens was calibrated with a graticule).

\section{Quantification of percentage blebbing cells}

The quantification of the percentage of blebbing cells was previously described [6]. Plates and $\mu$-dishes were properly fitted on the stages of a phase contrast Zeiss A1 inverted microscope, and the total number of cells (blebbing and non-blebbing cells) were visualized using $\mathrm{x} 40$ objective lens, and manually counted. The percentage of blebbing cells was obtained by dividing the number of blebbing cells by the sum of blebbing and non-blebbing cells. The quotient was then multiplied by 100 .

\section{Determination of bleb speed}

To determine bleb speed, images were opened in ImageJ, and a straight line was drawn across the centre of each bleb from one end to the other using the 'straight' tool. This was termed 'bleb distance'. Similarly, the time it took each bleb to expand and retract was quantified by manually tracking the frame numbers during expansion and retraction, and then multiplied by 2 as movies were generated at 2 seconds per frame (i.e. the time elapsed between the first frame in which bleb expansion or retraction was observed and the last frame in which expansion or retraction ceased). Bleb speed was obtained by dividing the distance by the time.

\section{Analysis of bleb dynamics}

For analysis of bleb dynamics, bleb-induced cells cultured in 3D matrigel matrix in $\mu$-dishes were monitored in TiE200 microscope whose chamber was pre-warmed at a temperature of $37^{\circ} \mathrm{C}$ with $5 \% \mathrm{CO}_{2}$ supply. Time-lapse movies of blebbing cells were generated at a rate of one frame every 2 seconds for an experimental period of $10 \mathrm{~min}$ using 40x objective lens. Time-lapse movies were opened in imageJ and played manually by controlling the 'forward' and 'backward' buttons of the movie. As the movie progresses, the number of frames it took blebs to expand, stabilize and retract were carefully monitored and recorded, and then multiplied by 2 (since movies were generated 2 seconds/frame). Bleb lifespan was calculated as the summation of bleb expansion, stabilization and retraction.

\section{Immunocytochemistry}

Cells were seeded on coverslips in 6-well plates and incubated at $37^{\circ} \mathrm{C}$ with an atmospheric condition of $5 \% \mathrm{CO}_{2}$ supply for 24 hours for cells to adhere to coverslips. Culture media was aspirated and cells rinsed twice with pre-chilled PBS before fixing for $20 \mathrm{~min}$ with $4 \%(\mathrm{v} / \mathrm{v})$ paraformaldehyde. Cells were rinsed twice (10 min each) with PBS before permeabilizing with $0.2 \%(\mathrm{v} / \mathrm{v})$ triton $\mathrm{x}-100$ for $15 \mathrm{~min}$ at room temperature. Cells were blocked with $10 \%(\mathrm{v} / \mathrm{v})$ goat serum (Sigma) in PBS for $30 \mathrm{~min}$ and then incubated at room temperature with human anti-AQP1 antibody (1:200 dilution) in 1\% (v/v) goat serum for $1 \mathrm{~h}$. Primary antibodies were removed and cells rinsed 3 times (10 min each) with pre-chilled PBS, and further incubated for $1 \mathrm{~h}$ with secondary antibody (1:500) conjugated with Alexa fluor 488 (Invitrogen). Cover slips were transferred to microscope slides and cells counter-stained with Vectashield/DAPI mounting medium and allowed to set before taking for confocal microscopy.

\section{Western blotting}

HT1080 and ACHN cell lines were seeded on a 6-well plate overnight and transfected with human AQP1 siRNAs. For protein expression determination, cells were cultured to confluent on 6-well plates. Cells were harvested and lysed in radioimmunoprecipitation assay (RIPA) buffer in the presence of protease inhibitor cocktail (1:100). Proteins were electrophoresed on $15 \%$ polyacrylamide gels before transferring to PVDF membranes and blocked with 5\% non-fat milk in $0.1 \%$ TBS-tween. Membranes were incubated overnight at $4^{\circ} \mathrm{C}$ with human anti-AQP1, AQP3, AQP4 and AQP5 antibodies (1:1000). Secondary antibodies used were anti-mouse and anti-rabbit IgGHRP (1:2000). Anti-tubulin antibody was used as a loading control. Membranes were treated with enhanced chemiluminescence (ECL) reagents $\mathrm{A}$ and $\mathrm{B}$, and then developed with ImageQuant LAS 4000 machine (GE Healthcare Life Sciences).

\section{Statistical analysis}

Statistical significance was performed by one-way analysis of variance after Tukey's post hoc multiple comparison for three or more variables, while unpaired, two-tailed student's $t$ test was performed for two variables. GraphPad prism 5 software (GraphPad software, San Diego, CA) was used to perform all comparisons. All data were generated from at least three independent experiments in triplicate $(n=3)$, and $P$ values $<0.05$ were considered statistically significant.

\section{Results}

\section{Bleb induction in cancer cells}

At normal, uninhibited state, cancer cells including the human fibrosarcoma HT1080 and renal adenocarcinoma ACHN cell lines cultured in $3 \mathrm{D}$ hydrogels such as matrigel and collagen migrate as elongated mesenchymal cells using lamellipodia and filopodia, and degrade the ECM with invadopodia expressing matrix metalloproteinases (MMPs) [42]. We recently induced cancer cells to bleb in matrigel matrix by inhibiting matrix proteolysis [6], a technique that was modified from that previously reported [18]. The capability of six different human cancer cell lines - A172 (glioblastoma), A549 (lung carcinoma), ACHN (renal adenocarcinoma), HT1080 (fibrosarcoma), MDA-MB-231 (breast cancer) and Panc-1 (pancreatic cancer) to form bleb in Matrigel was screened by blocking the activities of MMPs with the general MMP inhibitor, batimastat BB-94 $(1 \mu \mathrm{M})$ and other surface proteases with protease inhibitor cocktail PIC (1:100) in the presence of caspase inhibitor set VI $(10 \mu \mathrm{M})$ to prevent apoptosis. As shown in Figure 1a, membrane blebs were formed only in the ACHN and HT1080 cell lines upon inhibition of matrix degradation. As membrane blebs could also result from apoptosis-induced cell death, we performed MTT assay to determine the viability of the blebbing cells, and as shown in Figure 1b, treatment with bleb-inducing agents did not impinge on the viability of cells, suggesting that the membrane blebs in HT1080 and ACHN cells were non-apoptotic. Furthermore, we asked whether these blebs are under the ROCK signalling pathway which has been reported to govern bleb formation in healthy and unhealthy cell $[5,43]$. Use of $5 \mu \mathrm{M}$ of ROCK inhibitor, Y27632 potently ablated cell blebbing (Figures $1 \mathrm{c}$ and $\mathrm{d}$ ), suggesting that these cells were blebbing normally like other cells. 
A
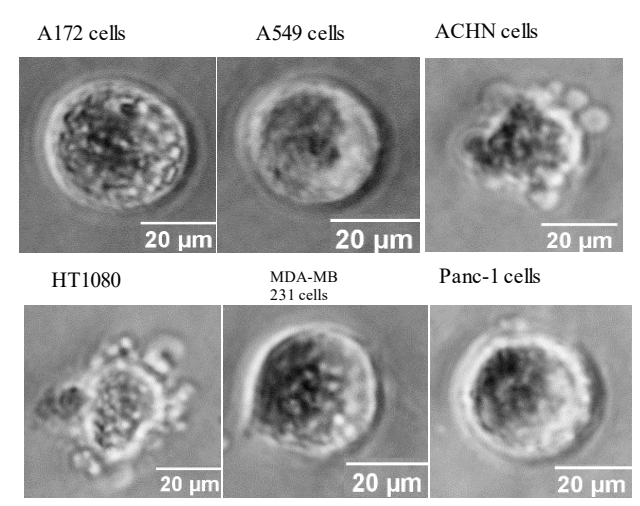

C

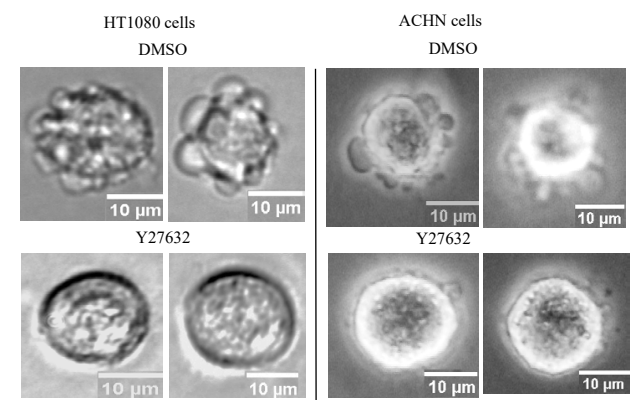

B

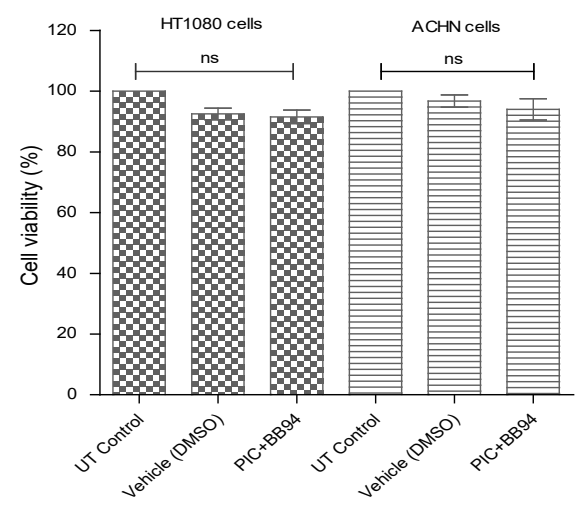

D

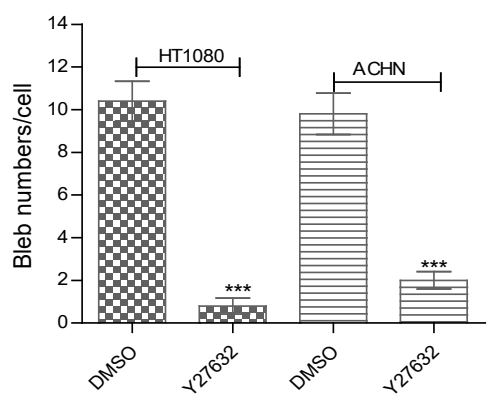

Figure 1. Bleb induction in cancer cells. (A) Cancer cells were induced to bleb in ECM by blocking matrix proteolysis with BB-94 (1 $\mu \mathrm{M})$ and PIC (1:100) in presence of caspase inhibitor set VI $(10 \mu \mathrm{M})$. Data is a representative of the means \pm SEM of three independent experiments in which 125 cells were scored for each cell line; (B) Determination of viability of BB-94and PIC-treated ACHN and HT1080 cell lines with MTT $(0.5 \mathrm{mg} / \mathrm{ml})$ in the dark at $37^{\circ} \mathrm{C}$ for $3 \mathrm{~h}$ before solubilizing with solubilization buffer. After thorough resuspension, samples were incubated at RT for $10 \mathrm{~min}$ and then vortexed before taking absorbance values using spectrophotometer; (C) Inhibition of ROCK signalling with Y27632; (D) Bleb numbers after inhibition of ROCK signalling;

\section{Detection of expression levels of AQPs in cancer cells}

We next assessed the expression levels of multiple AQPs previously shown to be involved in cancer in the profusely blebbing HT1080 cell line. As shown in Figure 2a, immunoblotting with human anti- AQP1, AQP3, AQP4 and AQP5 antibodies revealed very little or no expression of $A Q P 3$ and AQP4, whereas there was a high expression of AQP1 and AQP5. Similarly, the expression levels of AQP1, which is known to be involved in different human cancers (28) was assessed across all six cancer cell lines. As shown in figure $2 \mathrm{~b}$, the protein was found expressed in all six cell lines tested.

\section{siRNA-mediated knockdown of AQP1 inhibits bleb formation}

As AQP1 is the best characterized, and has been reported to be involved in the lamellipodial-based migration of different human cancer cells $(28,36,44)$, we investigated the potential role of the water channel in the formation of membrane blebs in HT1080 and ACHN cells by using smartpool siRNAs to knockdown the protein. By using Western blotting, we confirmed that protein knockdown in both cell lines occurred at $24 \mathrm{~h}$ (Figures $3 \mathrm{a}$ and $\mathrm{b}$ ), and this persisted in the ACHN cell line for up to $48 \mathrm{~h}$ post-transfection (Figure $3 \mathrm{~b}$ ). As anticipated, AQP1 knockdown inhibited membrane bleb formation in both cell lines (Figure 3d and e).

\section{Perturbation of AQP1 activity prolongs bleb lifespan}

In the HT1080 cell line, although, AQP1 knockdown was confirmed at the $24 \mathrm{~h}$ time point, with the concomitant ablation of bleb formation (Figures $3 \mathrm{~d}$ and e), expression of the protein did resurface at $48 \mathrm{~h}$ (figure $3 \mathrm{a}$ ) and this paralleled re-emergence of membrane blebs at that time point (Figure $3 \mathrm{f}$ ). Thus, it was imperative to undertake a comparative analysis of the life cycle of blebs in wildtype cell and those in the $48 \mathrm{~h}$ siRNA-transfected cells. A detailed analysis of bleb dynamics by tracking time-lapse movies of live blebbing cells revealed that blebs in AQP1-impaired cells expanded, stabilized and retracted much more slowly $(9.7,3.9$ and 14.3 seconds respectively) than those in wild-type cells (7.0, 3.0 and 10.3 seconds respectively) (Figures $4 \mathrm{a}, \mathrm{b}$ and c). As cellular bleb lifespan consists of expansion, stabilization and retraction, the net effect of this data was a longer bleb lifespan in the cells in which AQP1 activity was perturbed (28.1 seconds) as compared with blebs in wild-type cells (Figure 4D). Taken together, the data demonstrate that AQP1 activity is crucial for plasma membrane bleb formation in cancer cells.

\section{Effects of AQP1-GFP overexpression on bleb morphology}

To further study the role of AQP1 in the formation of plasma membrane blebs, the protein was overexpressed in cells by transfecting 
A

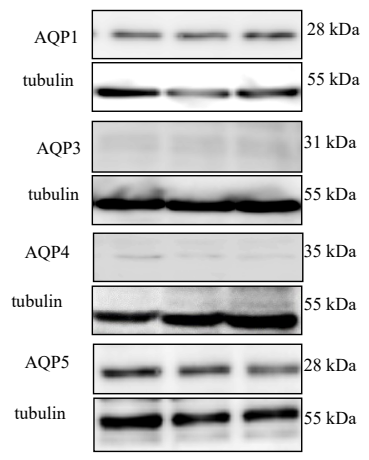

B

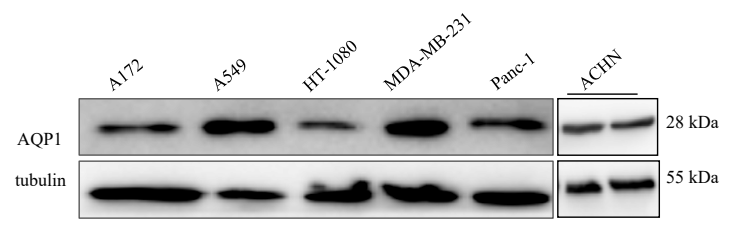

Figure 2. Detection of expression levels of AQPs in cancer cells. (A) Expression levels of AQP1, AQP3, AQP4 and AQP5 in profusely blebbing HT1080 cell line; (B) Expression levels of AQP1 in different human cancer cell lines by Western blotting. In both cases tubulin was used as a loading control. Data is the means \pm SEM of three independent experiments performed in triplicate $(\mathrm{n}=3)$. $* * *: \mathrm{P}<0.001$, using one-way ANOVA after Tukey's multiple comparison test.

A

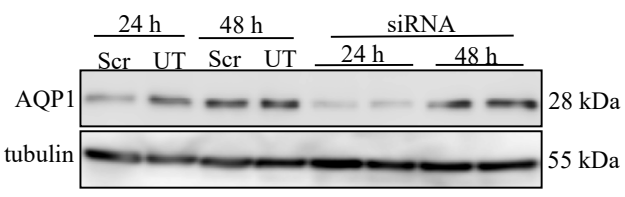

C

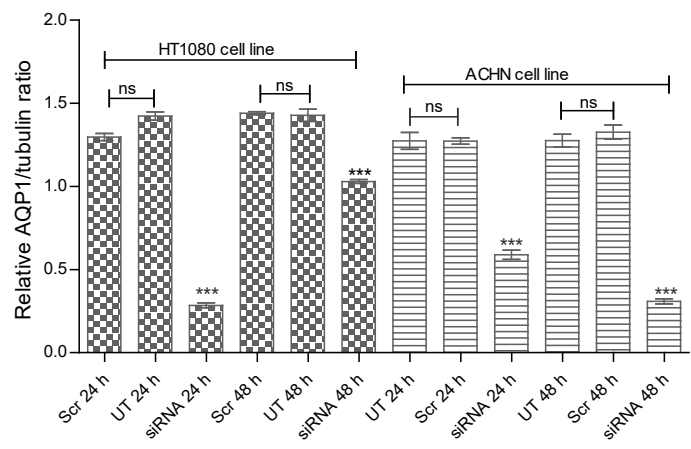

\section{E}

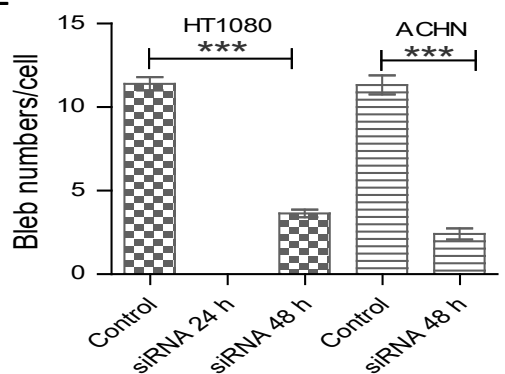

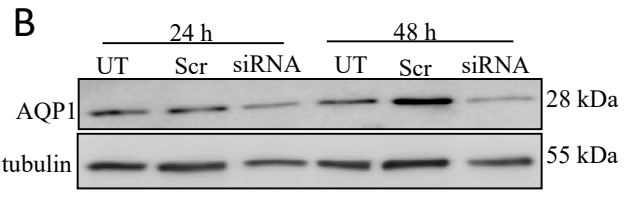

D

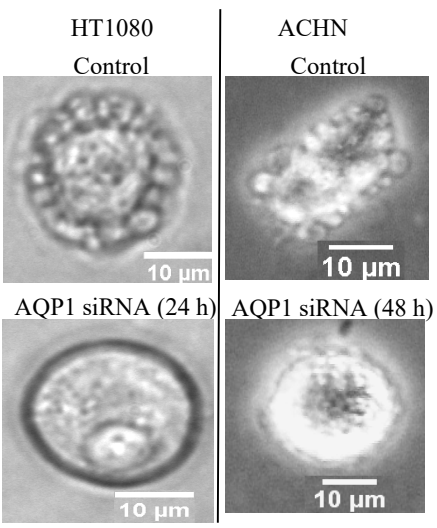

HT1080

F siRNA (48 h)
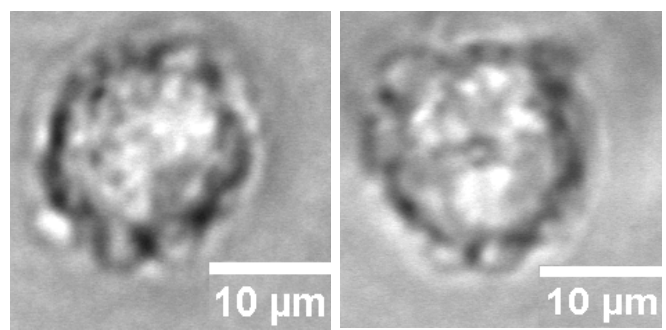

Figure 3. siRNA-mediated knockdown of AQP1 inhibits bleb formation. Cells were cultured on $75 \mathrm{~cm}$ flasks and transfected for $24 \mathrm{~h}$ to $48 \mathrm{~h}$ with human AQP1 siRNA using DharmaFECT transfection reagent set 4. Cells were lysed using RIPA buffer in presence of protease inhibitor cocktail PIC (1:100 dilution). Proteins were resolved on a 15\% SDS gel and immunoblotted with human anti-AQP1 antibody (1:1000 dilution). Tubulin was used as a loading control. (A) Immunoblot of AQP1 knockdown in HT1080 cells; (B) Immunoblot of AQP1 knockdown in ACHN cells; (C) Densitometric quantification of AQP1 levels in HT1080 and ACHN cell lines after normalization to tubulin loading control; (D) AQP1 siRNA-transfected HT1080 and ACHN cells were embedded in 3D matrigel and challenged with $1 \mu \mathrm{M}$ BB-94 and PIC (1:100 dilution) in the presence of $10 \mu \mathrm{M}$ caspase inhibitor set VI. In HT1080 and ACHN cells, AQP1 siRNA at $24 \mathrm{~h}$ and $48 \mathrm{~h}$ respectively, inhibited membrane bleb formation (bottom panels); (E) Quantification of number of membrane blebs; (F) Recurrence of membrane blebs in HT1080 cells $48 \mathrm{~h}$ post-AQP1 siRNA transfection. Data is a representative of the mean \pm SEM of three independent experiments performed in triplicate in which 120 cells were scored for each treatment. $* * *: \mathrm{P}<0.001$, using one-way ANOVA after Tukey's multiple comparison test. 
A

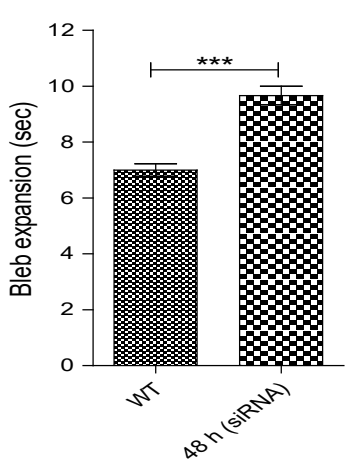

C

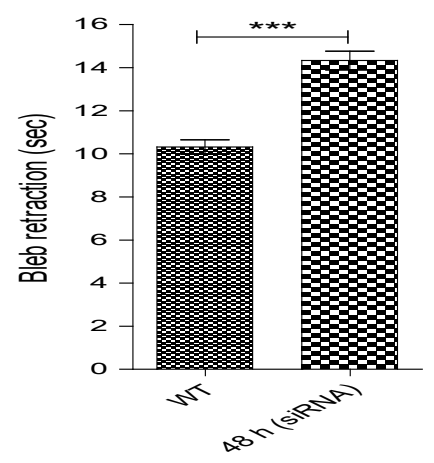

B

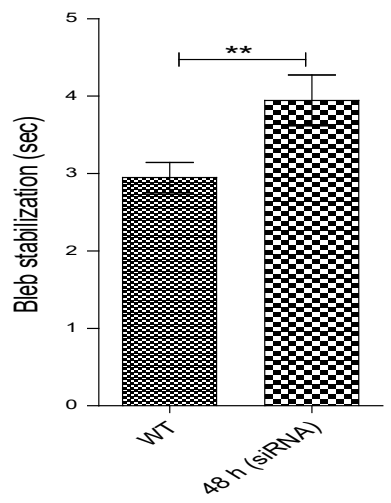

D

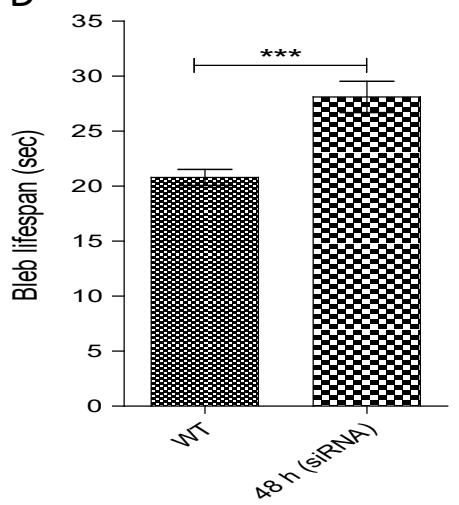

Figure 4. Perturbation of AQP1 activity prolongs bleb lifespan. AQP1 impairment at $48 \mathrm{~h}$ in HT1080 cells significantly increased time of: (A) bleb expansion; (B) bleb stabilization, and (C) bleb retraction; (D) Impaired AQP1 activity confers longer bleb lifespan. Data represent the mean \pm SEM of three independent experiments performed in triplicate in which 120 cells were scored for each treatment. $* * *: \mathrm{P}<0.001$, using two-tailed unpaired student's $\mathrm{t}$ test.

them with AQP1-GFP. Upon overexpression, more AQP1 was found localized to bleb membranes than other remaining cellular plasma membranes (Figure 5a). Quantification of AQP1-GFP fluorescence intensity along the bleb and cellular membranes revealed more than a two-fold increase of AQP1 level in membrane bleb than in the other parts of cell membrane (Figure 5b). We next, studied the morphological alterations induced by AQP1-GFP overexpression by quantifying, and comparing the sizes and numbers of blebs in AQP1-GFP-transfected cells to those of wild-type cells. It was discovered that AQP1-GFP overexpression in both HT1080 and ACHN cell lines induced a nearly two-fold increase in the size of membrane blebs (Figures $5 \mathrm{c}$ and $\mathrm{d}$ ). However, there was a significant decrease in bleb numbers upon AQP1GFP overexpression (Figures 5e).

As AQP1-GFP overexpression resulted in enlarged bleb sizes in both HT1080 and ACHN cell lines, we hypothesized that it could also induce bleb formation in non-blebbing cell lines. This hypothesis was tested in the metastatic human breast adenocarcinoma cell line, MDAMB-231, which did not form membrane blebs in 3D matrigel despite their higher expression of endogenous AQP1 levels (Figure 2b). This cell line only displayed tiny spike-like structures (figure $5 \mathrm{f}$, upper panel). However, as shown in figure 5f (bottom panel), AQP1-GFP overexpression sufficiently induced bleb formation in MDA-MB-23 cells.

\section{AQP1-GFP overexpression facilitates bleb retraction phase}

Since AQP1 overexpression resulted in an increase in bleb size, we first sought to know how dynamic those blebs were, and whether they behave like the blebs in wild-type cells. Therefore, phase contrast time-lapse movies of blebbing AQP1-overexpressing HT1080 cells were generated and the different phases of a cellular bleb life cycle were tracked. Detailed analysis revealed that the time of expansion of blebs in AQP1-GFP overexpressing and wild-type cells was not significantly different (Figures 6a). Similar result was obtained for bleb stabilization time (Figure 6b). However, it was discovered that AQP1GFP overexpressing cells retracted their blebs in a relatively shorter time (faster) than blebs in wild-type cells (Figure 6c), and this conferred on the former, a shorter bleb lifespan (Figure 6d). Furthermore, we tracked the speed (the ratio of bleb distance/circumference to time) of bleb expansion and retraction, and found no significant difference in the wild-type cells (Figure 6e). However, interestingly, and importantly, AQP1 overexpression significantly increased bleb retraction speed than that of expansion (Figure 6e). Taken together, the data demonstrate that AQP1 regulates membrane bleb formation by facilitating the bleb retraction phase.

\section{AQP1-facilitated bleb retraction requires $\mathrm{Na}^{+} / \mathrm{H}^{+}$exchanger activity}

Recent studies have demonstrated that when tumour cells are confined in a microchannel, they establish a polarized distribution of aquaporins and $\mathrm{Na}^{+} / \mathrm{H}^{+}$exchanger with the net influx and efflux of water through the leading and trailing edges respectively, and this drives migration of cell from one point to another [45]. Therefore, we hypothesized that the AQP1-facilitated bleb retraction could be in part, due to either influx of $\mathrm{Na}^{+}$with its accompanying intracellular alkalinisation or extracellular acidification due to proton extrusion by the $\mathrm{Na}^{+} / \mathrm{H}^{+}$pump. To test this hypothesis, the channel activity of the 
A

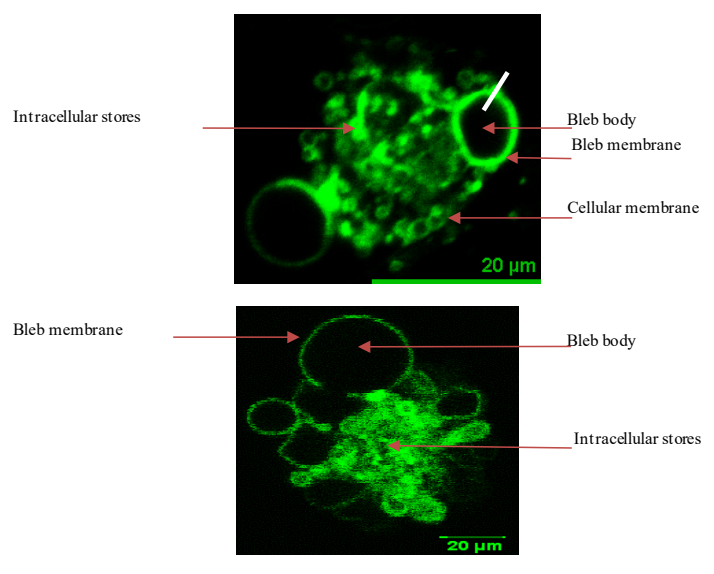

D

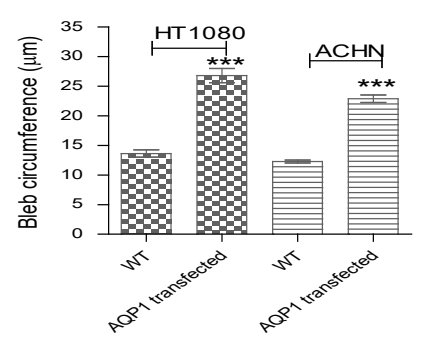

B

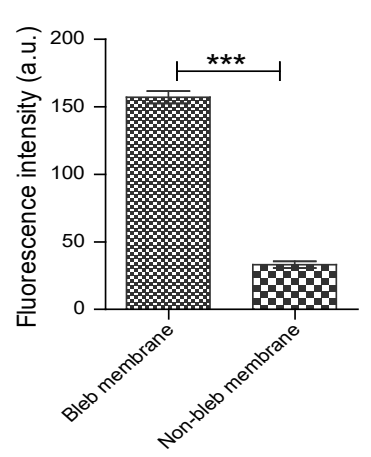

C

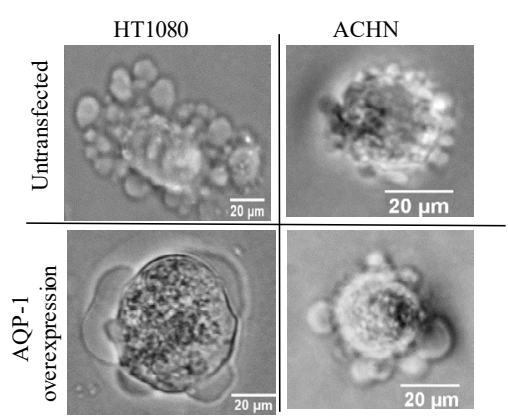

E

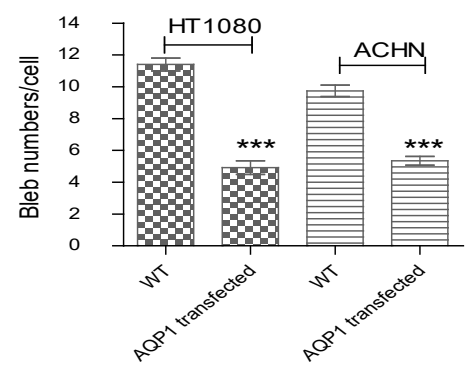

F

Non-transfected

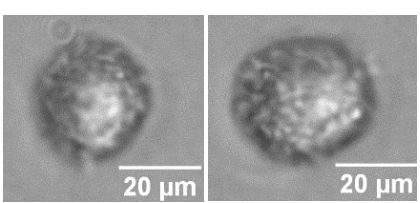

AQP1-GFP transfected
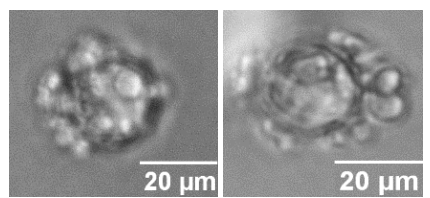

Figure 5. Effects of AQP1-GFP overexpression. (A) AQP1-GFP overexpression in ACHN (top panel) and HT1080 (bottom panel) reveals more localization of the protein at bleb membranes than other parts of cellular membrane; (B) Quantification of fluorescence intensity of AQP1-GFP expression in bleb and cellular membranes; (C) Phase contrast images of bleb morphologies in AQP1-GFP overexpressing cells; (D and E) Quantification of bleb size (circumference) and numbers respectively in HT080 and ACHN cell lines; (F) AQP1-GFP overexpression induced blebbing phenotype in MDA-MB-231 cells. Data is a representative of three independent experiments performed in triplicate $(\mathrm{n}=3)$ in which 120 cells were scored ${ }^{* * *}: \mathrm{P}<0.001$, using two-tailed unpaired student's $\mathrm{t}$ test, and one-way ANOVA after Tukey's multiple comparison test. 
A

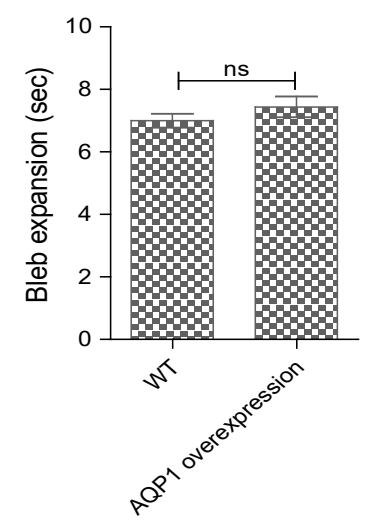

D

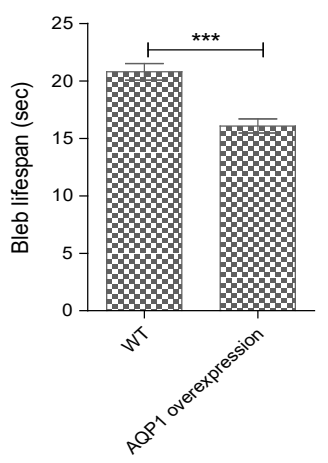

B

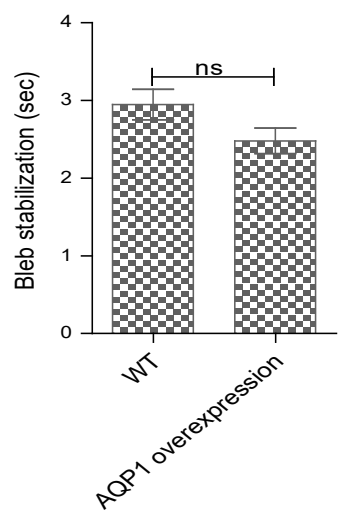

$\mathrm{E}$

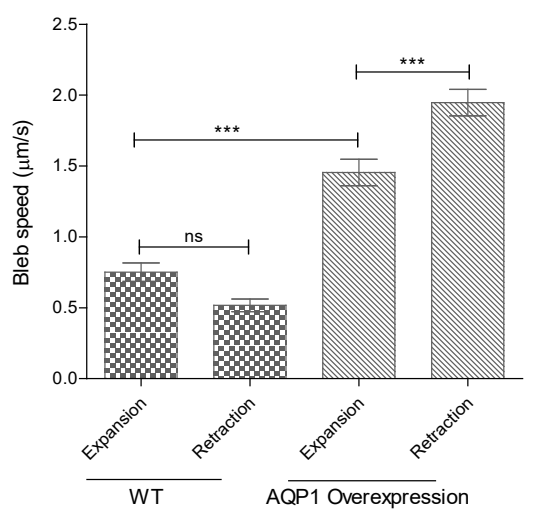

C

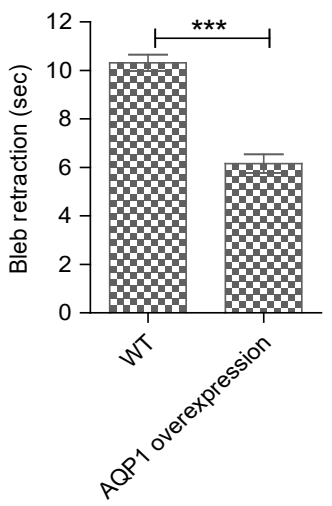

Figure 6. AQP1-GFP overexpression facilitates bleb retraction phase. HT1080 cells transfected with AQP1-GFP were cultured in matrigel and treated with bleb-inducing agents and incubated at $37^{\circ} \mathrm{C}$ overnight before generating phase contrast, time-lapse movies at $2 \mathrm{sec} /$ frame for an experimental length of 10 min. (A) Bleb expansion time in wild-type and AQP1-overexpressing HT1080 cells is not significantly different; (B) Bleb stabilization time in wild-type and AQP1-overexpressing HT1080 cells is not significantly different; (C) AQP1overexpressing cells retract their blebs faster than those in wild-type cells; (D) AQP1-overexpressing cells have shorter bleb lifespan than wild-type cells; (E) Whereas speed of bleb expansion and retraction was not significantly different in wild-type HT1080 cells, AQP1-GFP overexpression significantly increased speed of bleb retraction than bleb expansion speed. Data represents the means \pm SEM of three independent experiments performed in triplicate. ${ }^{* * *}: \mathrm{P}<0.001$, using two-tailed unpaired student's $t$ test, and one-way ANOVA after Tukey's multiple comparison test.

pump in ACHN and HT1080 cells was blocked for 15 min with the $\mathrm{Na}^{+} / \mathrm{H}^{+}$pump inhibitor, ethylisopropyl amiloride (EIPA), an effect that would result in intracellular acidification and extracellular alkalinisation due to proton and $\mathrm{Na}^{+}$accumulation respectively. As shown in figures $7 \mathrm{a}$ and $\mathrm{b}$ (bottom panels), pre-treatment of AQP1-GFP overexpressing cells with $100 \mu \mathrm{M}$ EIPA inhibited bleb retraction. Membrane blebs were found only expanding without any visible retraction, and this resulted in more than a four-fold increase in bleb size as compared to control cells (Figure 7c). With this observation, it was thought that bleb retraction might be slowed and that longer time periods would allow retraction to be observed. Inhibition of $\mathrm{Na}^{+} / \mathrm{H}^{+}$in the HT1080 cell line for 30, 60 and 90 min with EIPA had no significant effect on bleb size (Figure 7d). However, in the ACHN cell line, a gradual, time-dependent increase in size occurred, and the size difference became significant at the $90 \mathrm{~min}$ time point (Figure $7 \mathrm{~d}$ ). In both cell lines, blebs were only expanding without any observable retraction, suggesting that the AQP1-facilitated bleb retraction requires the $\mathrm{Na}^{+} / \mathrm{H}^{+}$pump activity.

\section{Discussion}

Several pathological conditions have been attributed to impaired aquaporins functions. Of particular interest is the discovery that the
AQP1 water channel not only facilitates water passage, but is involved in angiogenesis, cell proliferation, cell migration, cell adhesion and carcinogenesis $[28,39,40,46]$. Thus, there is the need for a critical evaluation of its role in cancer metastasis and other pathological conditions. However, despite its involvement in the lamellipodialbased cell migration and tumourigenesis, the role of the AQP1 in bleb formation and blebbing of cancer cell in the ECM has not been investigated.

Therefore, the present study started investigation of plasma membrane bleb formation by screening for the ability of six different human cancer cell lines, namely, A172 (glioblastoma), A549 (lung carcinoma), ACHN (renal adenocarcinoma), HT1080 (fibrosarcoma), MDA-MB-231 (breast adenocarcinoma) and Panc-1 (pancreatic cancer) to bleb in the ECM. The screening which was performed by inhibiting the proteolytic activities of MMPs and other surface proteases, found only the ACHN and HT1080 cell lines blebbing upon inhibition of matrix degradation (Figure 1a). These blebs were non-apoptotic as the activity of caspases which are known to execute programmed cell death were inhibited. Besides, the membrane blebs in the cells were actively and dynamically expanding and retracting. We further confirmed 
A

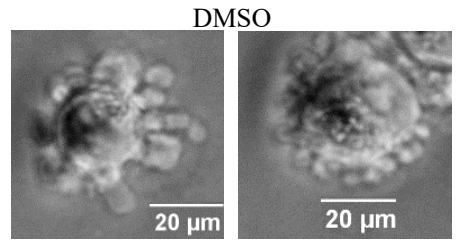

EIPA

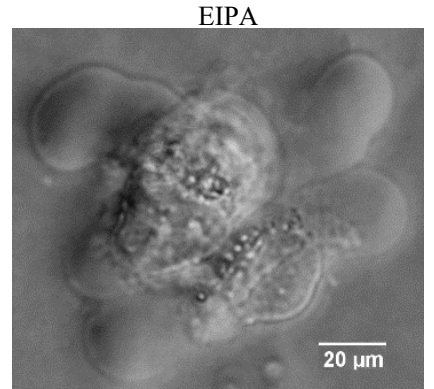

$\mathrm{C}$

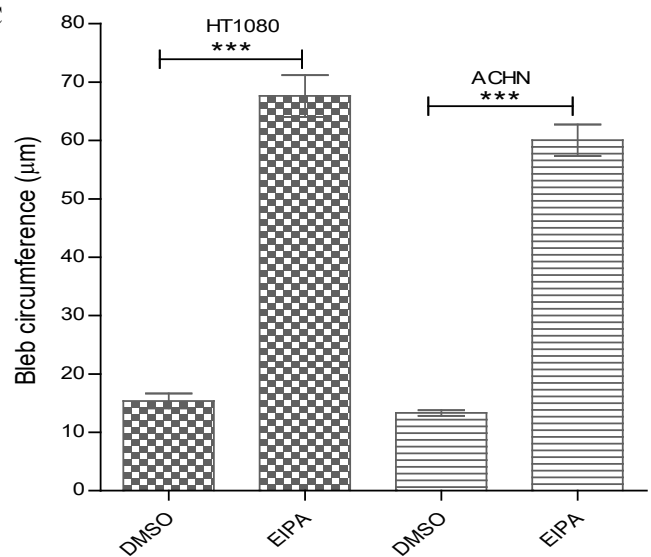

B
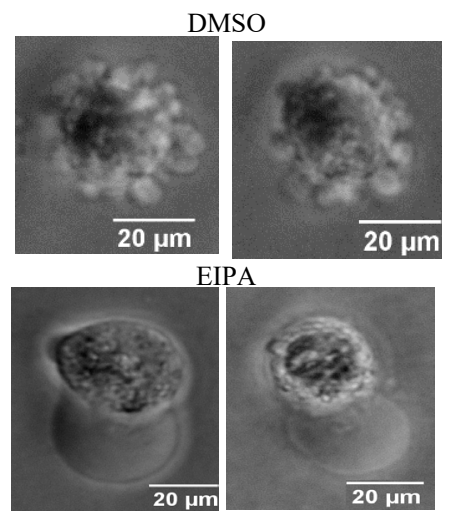

$\mathrm{D}$

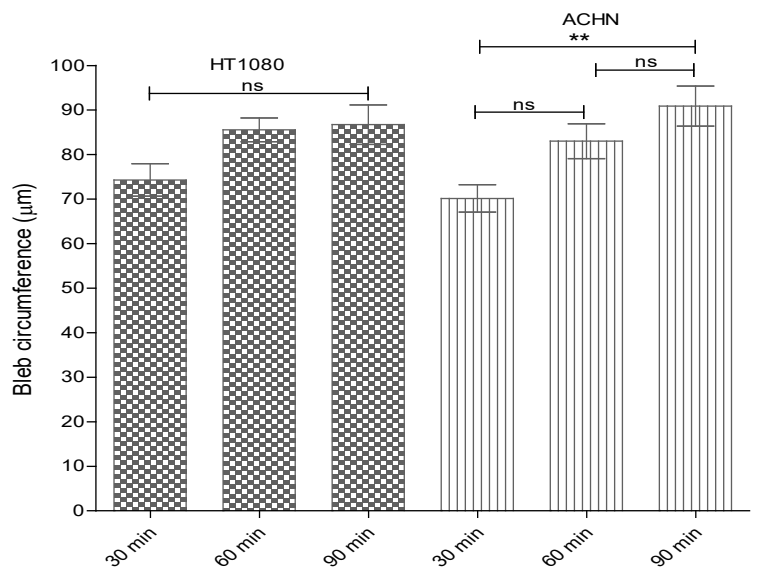

Figure 7. AQP1-facilitated increase of bleb retraction requires $\mathbf{N a}^{+} / \mathbf{H}^{+}$pump activity. AQP1-GFP overexpressing HT1080 and ACHN cell lines were cultured in $3 \mathrm{D}$ matrigel and then challenged with BB-94 $(1 \mu \mathrm{M})$ and PIC (1:100) in presence of caspase inhibitor set VI (10 $\mu \mathrm{M})$. Cells were pre-treated with EIPA (100 $\mu \mathrm{M})$. (A) and (B) EIPA blocked bleb retraction in HT1080 and ACHN cells respectively (bottom panels); (C) Quantification of bleb size upon EIPA treatment of cells; (D) Time course of EIPA treatment of cells. Data is a representative of the means \pm SEM of three independent experiments performed in triplicate in which 120 cells were scored. ${ }^{* * *}: \mathrm{P}<0.001$, using one-way ANOVA after Tukey's multiple comparison test.

that the cells survived bleb-inducing agents, as determination of cell viability through MTT assay showed $91.53 \%$ and $93.98 \%$ viability for the HT1080 and ACHN cells respectively (Figure 1b). Furthermore, it was imperative to establish whether these blebs conformed to, and are under the influence of the Rho-ROCK signalling pathway which has been widely reported to govern bleb formation in both healthy and apoptotic cells [43]. Inhibition of ROCK with its known inhibitor, Y27632, effectively blocked bleb formation in both cell lines (Figure 1c). Having confirmed the viability of cells and a requirement for Rho-ROCK signalling in bleb formation, we went on to investigate the role of the AQP1 in the formation of membrane blebs in cancer cells embedded in ECM.

Initially, we investigated the expression levels of AQP1, AQP3, AQP4 and AQP5, which have been previously implicated in different cancers [28,47-51], in the profusely blebbing HT1080 cells, and detected expression of only AQP1 and AQP5 in this cell line (Figure 2a). Furthermore, by using Western blotting, AQP1, which is the best characterized of all known AQP isoforms was found expressed across the other five different cancer cell lines, with the non-blebbing
MDA-MB-231 and A549 cell lines showing highest endogenous AQP1 expression levels (Figure 2b), suggestive of the fact that the expression levels of AQP1 does not necessarily confer blebbing capabilities on cells. The AQP water channels are mainly localized in the plasma membrane, although, they are also found localized in cytosolic compartments, and they do translocate to the plasma membrane in response to activation by hormones and kinases [52]. For instance, a PKA-dependent AQP1 phosphorylation and plasma membrane translocation has been reported in oocytes [53], and in astrocytes, hypotonicity-induced AQP1 translocation has been shown [54]. Similarly, in HEK293 cells, it has been reported that AQP1 was trafficked to the plasma membrane in a PKC-dependent mechanism [55]. It might therefore be that most of the AQP1 in the non-blebbing MDA-MB-231 and A549 cells could be localized to the cytosol, and that a plasma membrane translocation mechanism might be required for these cells to bleb. Indeed, immunocytochemical staining with human anti-AQP1 antibody indicated AQP1 expression at the plasma membranes of both ACHN and HT1080 cells, whereas, the protein was mainly expressed in the cytosolic compartment of MDA-MB-231 cell line (data not shown). Also, it could be that the expression of only AQP1 is not sufficient for 
these cells to bleb, and that other regulators are required, but might be absent in these cell lines.

Investigation of the role of AQP1 in plasma membrane bleb formation by siRNA-mediated gene knockdown revealed that AQP1 promotes membrane bleb formation in both HT1080 and ACHN cells, as knockdown of the protein in both cell lines $(24 \mathrm{~h}$ postsiRNA transfection) abrogated bleb formation (Figures $3 \mathrm{a}, \mathrm{b}$ and $\mathrm{d}$ ). Importantly, in the HT1080 cells, it was discovered that blebs started reappearing $48 \mathrm{~h}$ post-siRNA transfection (Figure $3 \mathrm{f}$ ), and this event paralleled the expression of AQP1 protein at the same time point (Figure 3a). An investigation of the dynamics of the reemergent blebs at $48 \mathrm{~h}$ post-AQP1 siRNA transfection and those in wild-type HT1080 cells was performed by taking a detailed analysis of bleb life cycle which consists of expansion, stabilization and retraction phases [56]. It was found that the reemergent blebs had longer lifespan than blebs in wild-type cells due to the longer time it took the former to expand, stabilize and retract their membranes (Figures $4 \mathrm{a}, \mathrm{b}$ and $\mathrm{c}$ ). One possible explanation for this observation could be that although, blebs re-emerged at $48 \mathrm{~h}$ post-AQP1 siRNA transfection, the siRNA treatment negatively impacted on AQP1 activity resulting in a defective water transport mechanism that impeded the rapid flux of water across plasma membrane, and this caused a delay in the flow of cytosolic fluids into the growing bleb. As actin repolymerization and recruitment of cortex-membrane linker proteins are factors known to mediate bleb retraction [5], it is not out of place to speculate that the impaired AQP1 activity could also hinder actin repolymerization as well as recruitment of cortex-membrane linker proteins such as the ERM proteins. An important implication of this finding is that impairment of AQP1 activity in blebbing cells will result in longer time to complete the bleb cycle, and so, such cells will undergo a slow and abnormal blebbing migration, whereas, in wild-type cells where there is faster rate of water and fluid passage, the bleb cycle will be completed in a relatively shorter period, and thus, the cells will not only migrate faster, but also become more aggressive and invasive.

To get further insights into the roles of AQP1 in the formation of membrane blebs in cancer cells, a GFP-tagged AQP1 was overexpressed in both blebbing ACHN and HT1080 cell lines, and it was discovered that in both cell lines, AQP1 localized to membrane blebs (Figure $5 a)$. Quantification of AQP1-GFP fluorescence intensity showed more than a two-fold concentration of AQP1 in bleb membranes than the remaining cellular membranes (Figure 5b). In accordance with previous reports that AQP1 could also be cytoplasmic [52], a high intracellular stores of AQP1 was also observed in the HT1080 cell line (figure 5a, bottom panel). AQP1 overexpression has been previously reported to be associated with cell swelling and volume increase [54,57], thus, we anticipated that AQP1 overexpression might modulate bleb morphology in our cell lines. Indeed, live-cell imaging to assess the morphological alterations upon AQP1-GFP overexpression revealed that AQP1 overexpression significantly increased the sizes of blebs (figure $5 \mathrm{c}$ and $\mathrm{d}$ ) with a concomitant decrease in the number of blebs (Figure 5e) in both cell lines. The effect of AQP1 overexpression on bleb size was more profound in the HT1080 cells as those blebs were significantly larger than blebs in the ACHN cell line (Figure 5c). Whether the HT1080 cells express more aquaporin water channels than the ACHN cell is not clear, however, western blotting data from this study showed no significant difference in the expression levels of AQP1 in both cell lines (Figure 2b). Next, we took advantage of the morphological increase in bleb size upon AQP1 overexpression to investigate the effect of the protein's overexpression in non-blebbing aggressive human breast adenocarcinoma MDA-MB-231 cell line.
Surprisingly, AQP1 overexpression effectively induced bleb formation in this cell line (Figure 5f), further confirming that AQP1 positively regulates bleb formation across different cell lines. However, whether the induction of bleb formation in non-blebbing cells by AQP1 is cell type-specific or not is yet to be addressed.

An analysis of the dynamics of the blebsin AQP1-GFP overexpressing and wild-type HT1080 cells showed no significant difference in bleb expansion and stabilization (Figures 6a and b). However, AQP1overexpresing cells retracted their blebs much faster $(6.2 \mathrm{sec})$ than the wild-type cells $(10.3 \mathrm{sec}$ ) (Figure $6 \mathrm{c}$ ), and this conferred a shorter bleb lifespan on the AQP1-overexpressing cells (figure 6d). Furthermore, a track of the speed of bleb expansion and retraction revealed no significant difference in the wildtype cells. However, upon AQP1-GFP overexpression, bleb retraction speed became significantly higher than that of expansion (Figure 6e), suggesting that AQP1 regulates membrane bleb formation by facilitating the retraction phase. This novel finding is quite interesting, as it suggests that the conventional view and belief of bleb retraction being mediated by actin repolymerization and recruitment of cortex-membrane linker proteins may not always be the case, as AQP1, and perhaps other AQPs can function independently or synergistically to permit rapid efflux of fluid out of cellular bleb to cause retraction.

To unravel the mechanism by which AQP1 facilitates bleb retraction, we investigated the possible involvement of the $\mathrm{Na}^{+} / \mathrm{H}^{+}$ pump which was previously reported to exhibit a polarized distribution together with the AQPs in tumour cells to mediate water and ion fluxes across the membrane thereby facilitating cell migration [45]. Normally, $\mathrm{Na}^{+}$influx into the cell by this pump is expected to be accompanied by obligated water inflow through AQP1 and this could lead to an increase in cytoplasmic pressure to drive bleb expansion. Surprisingly, the present study identified a requirement for the $\mathrm{Na}^{+} / \mathrm{H}^{+}$pump in AQP1-facilitated bleb retraction, as blockade of $\mathrm{Na}^{+}$influx and proton extrusion by inhibiting the activity of the antiporter with its known inhibitor, EIPA, completely blocked bleb retraction as well as formation of new blebs in both HT1080 and ACHN cell lines (Figures 7a and b). Cells were only found expanding, up to 90 minutes (maximum preincubation time) without any observable bleb retraction. Thus, we proposed that $\mathrm{Na}^{+} / \mathrm{H}^{+}$-mediated extracellular acidosis might activate acid signalling via plasma membrane acid-sensing ion channels (ASICs) to stimulate rapid outflow of water from an expanding bleb, thereby facilitating bleb retraction through AQP1 water channel. However, further studies are required to identify the specific isoform(s) of the $\mathrm{Na}^{+} / \mathrm{H}^{+}$pump involved, and a clear delineation on how intracellular alkalinisation and extracellular acidosis by this pump aids AQP1facilitated bleb retraction is required.

In conclusion, our data demonstrate for the first time, a novel role of AQP1 in regulating membrane bleb formation in HT1080 and ACHN cells. Specifically, we have shown that AQP1 accelerates the retraction phase of a cellular bleb via a mechanism that requires the $\mathrm{Na}^{+} / \mathrm{H}^{+}$ pump activity. As different cancer cells utilize plasma membrane blebs for dissemination through the extracellular matrix, AQP1 provides a potential therapeutic target in curbing cancer metastasis.

\section{Acknowledgements}

The authors thank Dr Matthew Conner (Sheffield Hallam University, UK) for supplying the GFP-tagged AQP1, Dr Sam Boateng and Dr Mike Fry (University of Reading, UK) for their advice, and Dr Henry Collins-Hooper (University of Reading, UK) for help with microscopy. 


\section{References}

1. Mierke CT (2015) Physical view on migration modes. Cell Adh Migr 9: 367-379. [Crossref]

2. Norman L, Sengupta K, Aranda-Espinoza H. Blebbing dynamics during endothelial cell spreading. European journal of cell biology. 2011;90(1):37-48. [Crossref]

3. Charras GT, Coughlin M, Mitchison TJ, Mahadevan L (2008) Life and times of a cellular bleb. Biophys $J$ 94: 1836-1853. [Crossref]

4. Aoki K, Maeda F, Nagasako T, Mochizuki Y, Uchida S, et al. (2016) A RhoA and Rnd3 cycle regulates actin reassembly during membrane blebbing. Proc Natl Acad Sci U S A 113: E1863-E1871. [Crossref]

5. Charras GT, Hu CK, Coughlin M, Mitchison TJ (2006) Reassembly of contractile actin cortex in cell blebs. J Cell Biol 175: 477-490. [Crossref]

6. Ponuwei GA, Dash PR (2016) Bleb Formation in Human Fibrosarcoma HT1080 Cancer Cell Line Is Positively Regulated by the Lipid Signalling Phospholipase D2 (PLD2). Achievements in the Life Sciences 10: 125-135.

7. Charras G, Paluch E (2008) Blebs lead the way: how to migrate without lamellipodia Nat Rev Mol Cell Biol 9: 730-736. [Crossref]

8. Coleman ML, Sahai EA, Yeo M, Bosch M, Dewar A, Olson MF (2001) Membrane blebbing during apoptosis results from caspase-mediated activation of ROCK I. Nat Cell Biol 3: 339-345. [Crossref]

9. Burton K, Taylor DL (1997) Traction forces of cytokinesis measured with optically modified elastic substrata. Nature 385: 450-454. [Crossref]

10. Boucrot E, Kirchhausen T (2007) Endosomal recycling controls plasma membrane area during mitosis. Proc Natl Acad Sci U S A 104: 7939-7944. [Crossref]

11. Bereiter-Hahn J, Luck M, Miebach T, Stelzer HK, Voth M (1990) Spreading of trypsinized cells: cytoskeletal dynamics and energy requirements. J Cell Sci 96: 171188. [Crossref]

12. Cunningham CC (1995) Actin polymerization and intracellular solvent flow in cell surface blebbing. J Cell Biol 129: 1589-1599. [Crossref]

13. Norman LL, Brugues J, Sengupta K, Sens P, Aranda-Espinoza H (2010) Cell blebbing and membrane area homeostasis in spreading and retracting cells. Biophys $J$ 99: 17261733. [Crossref]

14. Mercer J, Helenius A (2008) Vaccinia virus uses macropinocytosis and apoptotic mimicry to enter host cells. Science 320: 531-535. [Crossref]

15. Blaser H, Reichman-Fried M, Castanon I, Dumstrei K, Marlow FL, et al. (2006) Migration of zebrafish primordial germ cells: a role for myosin contraction and cytoplasmic flow. Dev Cell. 11: 613-627. [Crossref]

16. Lämmermann T, Sixt M (2009) Mechanical modes of 'amoeboid' cell migration. Curr Opin Cell Biol 21: 636-644. [Crossref]

17. Bergert M, Chandradoss SD, Desai RA, Paluch E (2012) Cell mechanics control rapid transitions between blebs and lamellipodia during migration. Proc Natl Acad Sci U S A 109: 14434-14439. [Crossref]

18. Wolf K, Mazo I, Leung H, Engelke K, von Andrian UH, et al. (2003) Compensation mechanism in tumor cell migration: mesenchymal-amoeboid transition after blocking of pericellular proteolysis. The J Cell Biol 160: 267-277. [Crossref]

19. Dajani S, Saripalli A, Sharma-Walia N (2018) Water transport proteins-aquaporins (AQPs) in cancer biology. Oncotarget 9: 36392-36405. [Crossref]

20. Kasa P, Farran B, Prasad GLV, Nagaraju GP (2019) Aquaporins in female specific cancers. Gene 700: 60-64. [Crossref]

21. Brown D (2017) The Discovery of Water Channels (Aquaporins). Ann Nutr Metab 70 37-42. [Crossref]

22. Gonen T, Walz T (2006) The structure of aquaporins. Q Rev Biophys 39: 361-396. [Crossref]

23. Tamma G, Valenti G, Grossini E, Donnini S, Marino A, et al. (2018) Aquaporin Membrane Channels in Oxidative Stress, Cell Signaling, and Aging: Recent Advances and Research Trends. Oxid Med Cell Longev: 1501847.

24. Agbani EO, Williams CM, Li Y, van den Bosch MT, Moore SF, et al. (2018) Aquaporin-1 regulates platelet procoagulant membrane dynamics and in vivo thrombosis. JCI Insight 3. [Crossref]

25. Aikman B, de Almeida A, Meier-Menches SM, Casini A (2018) Aquaporins in cancer development: opportunities for bioinorganic chemistry to contribute novel chemical probes and therapeutic agents. Metallomics 10: 696-712. [Crossref]
26. Madeira A, Fernandez-Veledo S, Camps M, Zorzano A, Moura TF, et al. (2014) Human aquaporin-11 is a water and glycerol channel and localizes in the vicinity of lipid droplets in human adipocytes. Obesity (Silver Spring) 22: 2010-2017. [Crossref]

27. Isokpehi RD, Rajnarayanan RV, Jeffries CD, Oyeleye TO, Cohly HH (2009) Integrative sequence and tissue expression profiling of chicken and mammalian aquaporins. $B M C$ Genomics 2: S7. [Crossref]

28. Papadopoulos MC, Saadoun S (2015) Key roles of aquaporins in tumor biology. Biochim Biophys Acta 1848: 2576-2583. [Crossref]

29. Verkman AS, Anderson MO, Papadopoulos MC (2014) Aquaporins: important but elusive drug targets. Nat Rev Drug Discov 13: 259-277. [Crossref]

30. Shi Z, Zhang T, Luo L, Zhao H, Cheng J, et al. (2012) Aquaporins in human breas cancer: identification and involvement in carcinogenesis of breast cancer. $J$ Surg Oncol 106: 267-272. [Crossref]

31. Chen R, Shi Y, Amiduo R, Tuokan T, Suzuk L (2014) Expression and prognostic value of aquaporin 1, 3 in cervical carcinoma in women of Uygur ethnicity from Xinjiang, China. PLoS One 9: e98576. [Crossref]

32. Xie Y, Wen X, Jiang Z, Fu HQ, Han H, et al. (2012) Aquaporin 1 and aquaporin 4 are involved in invasion of lung cancer cells. Clin Lab 58: 75-80. [Crossref]

33. Yang JH, Yu YQ, Yan CX (2011) Localisation and expression of aquaporin subtypes in epithelial ovarian tumours. Histol Histopathol 26: 1197-1205. [Crossref]

34. Yool AJ, Weinstein AM (2002) New roles for old holes: ion channel function in aquaporin-1. New Physiol Sci 17: 68-72. [Crossref]

35. Boassa D, Yool AJ (2002) A fascinating tail: cGMP activation of aquaporin-1 ion channels. Trends Pharmacol Sci 23: 558-562. [Crossref]

36. Verkman AS (2012) Aquaporins in clinical medicine. Annu Rev Med 63: 303-316. [Crossref]

37. King LS, Choi M, Fernandez PC, Cartron JP, Agre P (2001) Defective urinaryconcentrating ability due to a complete deficiency of aquaporin-1. N Engl J Med 345 : 175-179. [Crossref]

38. Zhang H, Verkman AS (2010) Aquaporin-1 tunes pain perception by interaction with $\mathrm{Na}(\mathrm{v}) 1.8 \mathrm{Na}+$ channels in dorsal root ganglion neurons. J Biol Chem 285: 5896-5906. [Crossref]

39. Dorward HS, Du A, Bruhn MA, Wrin J, Pei JV, et al. (2016) Pharmacological blockade of aquaporin-1 water channel by AqB013 restricts migration and invasiveness of colon cancer cells and prevents endothelial tube formation in vitro. $J$ Exp Clin Cancer Res 35: 36. [Crossref]

40. Saadoun S, Papadopoulos MC, Hara-Chikuma M, Verkman AS (2005) Impairment of angiogenesis and cell migration by targeted aquaporin-1 gene disruption. Nature 434 : 786-792. [Crossref]

41. Verkman AS, Hara-Chikuma M, Papadopoulos MC (2008) Aquaporins--new players in cancer biology. J Mol Med (Berl) 86: 523-529. [Crossref]

42. Ridley AJ (2011) Life at the leading edge. Cell 145: 1012-1022. [Crossref]

43. Paluch EK, Raz E (2013) The role and regulation of blebs in cell migration. Curr Opin Cell Biol 25: 582-590. [Crossref]

44. Papadopoulos MC, Saadoun S, Verkman AS (2008) Aquaporins and cell migration. Pflugers Arch 456: 693-700. [Crossref]

45. Stroka KM, Jiang H, Chen SH, Tong Z, Wirtz D, et al. (2014) Water permeation drives tumor cell migration in confined microenvironments. Cell 157: 611-23. [Crossref]

46. Moon C, Soria JC, Jang SJ, Lee J, Obaidul Hoque M, et al. (2003) Involvement of aquaporins in colorectal carcinogenesis. Oncogene 22: 6699-6703. [Crossref]

47. Deb P, Pal S, Dutta V, Boruah D, Chandran VM, et al. (2012 ) Correlation of expression pattern of aquaporin-1 in primary central nervous system tumors with tumor type, grade, proliferation, microvessel density, contrast-enhancement and perilesional edema. $J$ Cancer Res Ther 8: 571-577. [Crossref]

48. Saadoun S, Papadopoulos MC, Davies DC, Bell BA, Krishna S (2002) Increased aquaporin 1 water channel expression in human brain tumours. Br J Cancer 87: 621623. [Crossref]

49. Lee SJ, Chae YS, Kim JG, Kim WW, Jung JH, et al. (2014) AQP5 expression predicts survival in patients with early breast cancer. Ann Surg Oncol 21: 375-383. [Crossref]

50. Jung HJ, Park JY, Jeon HS, Kwon TH (2011) Aquaporin-5: a marker protein for proliferation and migration of human breast cancer cells. PLoS One 6: e28492. [Crossref] 
51. Nico B, Ribatti D (2010) Aquaporins in tumor growth and angiogenesis. Cancer Lett 294: 135-138. [Crossref]

52. Conner AC, Bill RM, Conner MT (2013) An emerging consensus on aquaporin translocation as a regulatory mechanism. Mol Membr Biol 30: 1-12. [Crossref]

53. Han Z, Patil RV (2000) Protein kinase A-dependent phosphorylation of aquaporin-1. Biochem Biophys Res Commun 273: 328-332. [Crossref]

54. Conner MT, Conner AC, Bland CE, Taylor LH, Brown JE, et al. (2012) Rapid aquaporin translocation regulates cellular water flow: mechanism of hypotonicityinduced subcellular localization of aquaporin 1 water channel. J Biol Chem 287: 1151625. [Crossref]
55. Conner MT, Conner AC, Brown JEP, Bill RM (2010) Membrane Trafficking of Aquaporin 1 Is Mediated by Protein Kinase $\mathrm{C}$ via Microtubules and Regulated by Tonicity. Biochemistry 49: 821-823. [Crossref]

56. Collins-Hooper H, Woolley TE, Dyson L, Patel A, Potter P, et al. (2012) Age-related changes in speed and mechanism of adult skeletal muscle stem cell migration. Stem Cells 30: 1182-1195. [Crossref]

57. Zhang J, Xiong Y, Lu LX, Wang H, Zhang YF, et al. (2013) AQP1 expression alterations affect morphology and water transport in Schwann cells and hypoxia-induced upregulation of AQP1 occurs in a HIF-1alpha-dependent manner. Neuroscience 252: 6879. [Crossref]

Copyright: (C2019 Ponuwei GA. This is an open-access article distributed under the terms of the Creative Commons Attribution License, which permits unrestricted use, distribution, and reproduction in any medium, provided the original author and source are credited. 